\title{
The relationship between plant species richness and soil aggregate stability can depend on disturbance
}

\author{
Mandy Pohl • Frank Graf • Alexandre Buttler • \\ Christian Rixen
}

Received: 28 June 2011 / Accepted: 22 November 2011 /Published online: 6 January 2012

(C) Springer Science+Business Media B.V. 2011

\begin{abstract}
Aims Plant diversity has been shown to significantly increase topsoil aggregate stability of machine-graded ski slopes. We hypothesise that this effect is specific for these disturbed sites and that at sites of low and no disturbance the effect decreases.

Methods We determined plant species richness, cover percentage of five functional groups, root (length)
\end{abstract}

Responsible Editor: Alexia Stokes.

M. Pohl $\cdot$ F. Graf $\cdot$ C. Rixen $(\bowtie)$

WSL Institute for Snow and Avalanche Research SLF,

Unit Community Ecology, Mountain Ecosystems,

Flüelastrasse 11,

7260 Davos Dorf, Switzerland

e-mail: rixen@slf.ch

A. Buttler

Swiss Federal Institute for Forest, Snow and Landscape

Research, Unit Community Ecology,

Pasture Woodlands and Wetlands,

POB 96, 1015 Lausanne, Switzerland

\section{Pohl · A. Buttler}

School of Architecture, Civil and Environmental

Engineering ENAC, Ecole Polytechnique Fédérale de

Lausanne EPFL, Laboratory of Ecological Systems ECOS,

Station 2,

1015 Lausanne, Switzerland

A. Buttler

Laboratoire de Chrono-Environnement, UMR CNRS 6249,

UFR des Sciences et Techniques,

Université de Franche-Comté,

16 route de Gray,

25030 Besançon, France density, and biomass as well as soil aggregate stability, gravimetric soil moisture, soil density, and particle size distribution at different levels of disturbance (i.e. graded and un-graded ski slopes and the surrounding area).

Results Plant species richness, vegetation cover, aggregate stability and soil moisture were significantly reduced on machine-graded slopes compared to control plots but hardly on un-graded slopes. On the contrary, machine-grading increased soil density and friction angle compared to un-graded ski slopes. The influence of species richness on aggregate stability was only positive on gravely soils and graded ski slopes. Aggregate stability increased linearly up to approximately eight plant species, $70 \%$ vegetation cover and $0.006 \mathrm{~g} \mathrm{~cm}^{-3}$ root density.

Conclusions Our study showed that the relationship between plant diversity and aggregate stability was strongest on slopes with high disturbance and relatively low species numbers. We suggest that high plant diversity, vegetation cover and root density need to be established after major human disturbance such as grading.

Keywords Alpine ecosystems · Grading · Plant functional groups $\cdot$ Roots $\cdot$ Ski slopes $\cdot$ Soil erosion

\section{Introduction}

Plant diversity and vegetation cover are hypothesised to play a key role for erosion control. That is because a vegetation cover with a high number of plant species of 
different growth forms, plant functional groups, and root characteristics will be more effective at governing soil erosion processes than a vegetation cover with few species and less different growth forms (Körner and Spehn 2002). However, the effects of plant diversity on erosion processes have only scarcely been demonstrated especially in alpine ecosystems above the treeline.

Vegetation affects the soil above- and below-ground: a dense plant canopy increases the surface roughness, acts as wind break and sediment trap, intercepts raindrops and transpires soil water (Zuazo and Pleguezuelo 2008). Our general understanding of the influence of roots on erosion is limited and mainly derives from slope stability research (Gyssels and Poesen 2003). Plant roots control both hydrological and mechanical properties. Roots create soil macro-pores and therefore increase the infiltration capacity; they bind loose soil particles and form a network in the ground. Most important for slope stability are plant roots that act in tension if they cross the potential slip surface and increase the soil shear strength due to mechanical reinforcement (Stokes et al. 2009). For soil erosion processes, roots can be thought of having a similar mechanical effect.

An indicator of soil susceptibility to runoff and erosion is soil aggregate stability. Aggregate stability is considered to be one of the main soil characteristics regulating soil erodibility since soil aggregate formation is linked to crusting and sealing that reduces the infiltration capacity and increases runoff (Amezketa 1999; Barthès and Roose 2002; Shinjo et al. 1999). For crop growth, for instance, good soil structure should comprise water stable soil aggregates composed of soil particles with 1 to $10 \mathrm{~mm}$ in diameter which should be porous ( $>75 \mu \mathrm{m}$ diameter) to remain aerobic, and possess pores $30-0.2 \mu \mathrm{m}$ in diameter to retain water for plant growth (Tisdall and Oades 1982). Un-stable aggregates slake when wetted rapidly as they are not strong enough to withstand the pressure of entrapped air in capillaries or the pressure due to swelling. Slaking occurs mainly in surface layers since those are not protected from air-drying and rapid wetting. Consequently, slaked soil layers limit the water infiltration and the plant growth (Tisdall and Oades 1982). Thus, tests on the water stability of soil aggregates best simulates the natural forces during heavy precipitation, and further are a relatively easy and feasible approach for the stateevaluation of soil erodibility (Barthès and Roose 2002; Bird et al. 2007; Frei et al. 2003; Shinjo et al.
1999). Aggregate stability not only refers to the soil structure in particular but plays a key role in ecosystem functioning in general, affecting water, gas and nutrient fluxes and storage and, therefore, contributes to biological diversity and activity specifically in the soil but also aboveground (Amezketa 1999; Elridge and Leys 2003; Wick et al. 2009). Factors controlling soil aggregate stability are commonly distinguished as abiotic (clay minerals, sesquioxides, exchangeable cations), biotic (soil organic matter, plant roots, soil fauna and microorganisms), and environmental (soil temperature and moisture) (Chen et al., 1998 in Márquez et al. 2004).

Positive effects of plant diversity (i.e. plant species richness) on soil aggregate stability have recently been studied by Pohl et al. (2009) in the Swiss Alps. They quantified aggregate stability from machine-graded ski slopes, and related aggregate stability to 1) abiotic soil properties, 2) aboveground vegetation characteristics and 3 ) root parameters. From the three groups of variables, sand content, plant diversity and root density showed the highest correlation with aggregate stability and explained $54 \%$ of its variance on machine-graded ski slopes. Plant diversity further showed to be the most relevant factor in explaining $19 \%$ of the variance in aggregate stability on machine-graded ski slopes. In this study, we explored data of graded and un-graded ski slopes and the surrounding area, and identify the role of vegetation, in particular of plant diversity, for aggregate stability at sites of low and no disturbance. We pooled our data with the data of Pohl et al. (2009) in an extensive statistical analysis. We raise the question if the pattern found by Pohl et al. (2009) is specific for disturbed sites (i.e. machine-graded ski slopes) or if it applies for sites of low and no disturbance (i.e. ungraded ski slopes, slopes with artificial snow and the surrounding area) in general. Our hypothesis is that plant species richness increases aggregate stability at disturbed sites, but that at sites of low and no disturbance more developed vegetation characteristics and soil properties become more important.

\section{Material and methods}

Study sites and experimental design

The study was conducted in the ski resorts Jakobshorn in Davos (N 46 $46^{\prime}, \mathrm{E}^{\circ} 50^{\prime}$ ), Lenzerheide (N 46 $46^{\prime}$, E $9^{\circ} 35^{\prime}$ ) and in Flims-Laax (N 46 50 , E $9^{\circ} 10^{\prime}$ ) in the 
Central Eastern Alps (Grison, Switzerland). The climate is alpine, with a mean annual temperature of $2.7^{\circ} \mathrm{C}$ and mean annual precipitations of $999 \mathrm{~mm}$ (station Davos at 1594 ma.s.l. from the year 1961 to 1990). Mean monthly temperature and total precipitation during the growing season (May-September) in Davos are $9.1^{\circ} \mathrm{C}\left( \pm 2.1^{\circ} \mathrm{C}\right)$ and $113.6 \mathrm{~mm}$, respectively. The study sites are covered with snow from the beginning of November till end of May. Most common vegetation are alpine pastures on mostly acidic bedrock with Carex curvula, Cetraria islandica, Cladina spp., Cladonia spp., Helictotrichon versicolor, Homogyne alpina, Leontodon helveticus, Ligusticum mutellina and Vaccinium myrtillus as dominant species. The study sites were chosen on machine-graded and un-graded ski slopes with either natural or artificial snow (Table 1, and Pohl et al. 2009). Machine-grading (i.e. construction of ski pistes

Table 1 Characteristics of plots on ski slopes and their control plots at three study sites. Along each ski slope, six plots on and six control plots adjacent to each ski slope were selected. Data are during which vegetation and topsoil are removed) had been carried out 16-44 years ago. Machine-grading is usually only applied once. At Lenzerheide, seed mixtures had been used for revegetation, but details of restoration techniques were not available. Along each ski slope, we randomly selected six plots on and six control plots adjacent to each ski slope. Plots were usually distributed across a stretch of several $100 \mathrm{~m}$ along each ski slope to make the study more representative for ski slopes in general. Plots were of small size $\left(20 \mathrm{~cm}\right.$ in diameter $\left.=314 \mathrm{~cm}^{2}\right)$, to limit the influence of spatial heterogeneity and to achieve a high total sample size ( 3 ski areas $* 4$ ski slopes $* 2$ treatments [on or off ski slope] $* 6$ replicates; total $n=144)$. Small plots sizes with appropriate replication have been used with success previously to cover the heterogeneity of ski slopes (Martin et al. 2010; Pohl et al. 2009), and different plot sizes of one and $20 \mathrm{~m}^{2}$ yielded comparable results in a

minimum and maximum values. Data in brackets represents control plots. na: not available

\begin{tabular}{|c|c|c|c|c|c|c|}
\hline Ski resort & Name of ski slope & Type of snow & Elevation (m a.s.1.) & Inclination $\left(^{\circ}\right)$ & Artificial snow since & Machine-graded in \\
\hline \multirow[t]{2}{*}{ Davos Jakobshorn } & 1 & Natural & $2306-2450$ & $13-35$ & - & - \\
\hline & Control & - & $(2293-2454)$ & $(10-20)$ & - & - \\
\hline \multirow[t]{2}{*}{ Davos Jakobshorn } & 11 & Artificial & $2307-2482$ & $10-20$ & 1995 & - \\
\hline & Control & - & $(2313-2469)$ & $(13-20)$ & - & - \\
\hline \multirow[t]{2}{*}{ Davos Jakobshorn } & 5 & Natural & $2302-2436$ & $12-25$ & - & 1965 \\
\hline & Control & - & $(2317-2438)$ & $(10-26)$ & - & - \\
\hline \multirow[t]{2}{*}{ Davos Jakobshorn } & 8 & Artificial & $2300-2471$ & $18-20$ & 1994 & 1965 \\
\hline & Control & - & $(2312-2492)$ & $(15-25)$ & - & - \\
\hline \multirow[t]{2}{*}{ Flims/Laax } & 24 & Natural & $2242-2378$ & $5-23$ & - & - \\
\hline & Control & - & $(2253-2375)$ & $(14-20)$ & - & - \\
\hline \multirow[t]{2}{*}{ Flims/Laax } & 15 & Artificial & $2256-2351$ & $9-24$ & 2006 & - \\
\hline & Control & - & $(2253-2329)$ & $(11-23)$ & - & - \\
\hline \multirow[t]{2}{*}{ Flims/Laax } & 41 & Natural & 2389-2435 & $14-20$ & - & 1973 \\
\hline & Control & - & $(2383-2439)$ & $(20-25)$ & - & - \\
\hline \multirow[t]{2}{*}{ Flims/Laax } & 66 & Artificial & 2119-2199 & $10-20$ & 1993 & 1970 \\
\hline & Control & - & $(2102-2186)$ & $(10-24)$ & & \\
\hline \multirow[t]{2}{*}{ Lenzerheide } & na & Natural & - & - & - & - \\
\hline & Control & - & - & - & - & - \\
\hline \multirow[t]{2}{*}{ Lenzerheide } & 7 & Artificial & $1967-2047$ & $14-25$ & na & - \\
\hline & Control & - & $(1953-2033)$ & $(10-29)$ & - & - \\
\hline \multirow[t]{2}{*}{ Lenzerheide } & 2,4 & Natural & $2427-2582$ & $15-25$ & - & 1993, 1988 \\
\hline & Control & - & $(2431-2574)$ & $(13-32)$ & - & - \\
\hline \multirow[t]{2}{*}{ Lenzerheide } & 5 & Artificial & $2164-2249$ & $20-25$ & na & 1993 \\
\hline & Control & - & $(2162-2252)$ & $(15-26)$ & & \\
\hline
\end{tabular}


study on surface erosion on alpine slopes (Schindler Wildhaber et al. 2011).

\section{Soil properties}

Two soil samples were taken from each plot using a $30 \mathrm{~cm}$-long cylindrical corer $(\mathrm{d}=5 \mathrm{~cm})$. The soil samples were cold stored at $4{ }^{\circ} \mathrm{C}$ and analysed within 14 days. One of the two soil cores was used to determine gravimetric soil moisture $\left(\mathrm{g} \mathrm{g}^{-1}\right)$ and soil density $\left(\mathrm{g} \mathrm{cm}^{-3}, 0-10 \mathrm{~cm}\right.$ soil depth) by oven drying at $105^{\circ} \mathrm{C}$ for $48 \mathrm{~h}$. With the second soil core, the stability of soil aggregates (\%) was quantified. To quantify the stability of soil aggregates, we used a modified wet sieving method after Frei et al. (2003). Therefore, the topmost 0 to $10 \mathrm{~cm}$ soil sample was placed on a $20 \mathrm{~mm}$ mesh-sieve and flooded with local spring water, the quality of which was close to precipitation water (conductivity $\sigma<100 \mu \mathrm{S} \mathrm{cm}^{-1}$, water hardness $<4^{\circ} \mathrm{f}$ ). After $5 \mathrm{~min}$, the water was drained and the remaining soil from the top sieve removed. The roots were then separated from the soil (see section on 'Aboveand below-ground vegetation characteristics'). The soil trapped by the sieve and the portion which passed through were oven-dried at $105^{\circ} \mathrm{C}$ for $24 \mathrm{~h}$ and weighed separately. Stable aggregates were represented by the proportion of the soil that did not pass through the $20 \mathrm{~mm}$ sieve over the entire soil sample minus the stones $>20 \mathrm{~mm}$. Approximate organic matter in all samples was determined in duplicates by combustion at $550^{\circ} \mathrm{C}$ for at least $2 \mathrm{~h}$ of $2 \mathrm{~mm}$ sieved dry soil (Bisutti et al. 2004). Particle size distribution was determined (1) by dry sieving the coarse fractions (gravel, $>2 \mathrm{~mm}$ ) and (2) by sedimentation for determining proportions of silt $(0.05-0.002 \mathrm{~mm})$ and clay $(<0.002 \mathrm{~mm})$ with the pipette analysis in duplicates (Gee and Bauder 1986). The proportion of sand (2$0.05 \mathrm{~mm}$ ) was calculated thereafter, and the soil material was classified (SN670005a 1997; SN670008a 1997). With this classification of the soil material, the tabular value of the angle of internal friction was determined (SN670010b 1999). Soil pH of each plot was measured in the field (pH-field kit Hellige, VWR International AG, Dietikon, Switzerland).

Above- and below-ground vegetation characteristics

From end of June to end of August 2007, we recorded in each plot the presence of all plant species and cover percentage of grasses, forbs, shrubs, mosses and lichen, and the cover percentage of the un-vegetated ground. Aboveground biomass ( $\mathrm{g}$ ) was harvested from the cylindrical corer $(\mathrm{d}=5 \mathrm{~cm})$ after taking the soil samples. The biomass was dried at $70^{\circ} \mathrm{C}$ and weighed.

Roots were removed from soil samples (see section on 'Soil properties' for sampling methods), washed and stored in $15 \%$ ethanol-water at $4^{\circ} \mathrm{C}$ until processing. Total root length was determined using the image analysing software WinRhizo (Regent Instrument, Quebec, Canada). Root length density (RLD $-\mathrm{cm} \mathrm{cm}^{-3}$ ) was calculated by dividing the mean length of the roots by the volume of the corresponding soil cylinder. Root density $\left(\mathrm{RD}-\mathrm{g} \mathrm{cm}^{-3}\right.$ ) was obtained by dividing dry mass of roots by the volume of the soil cylinder.

\section{Statistical analysis}

Differences in vegetation characteristics and soil properties between plots on ski slopes and their adjacent control plots were analysed with two-way Analysis of Variance (ANOVA). Ski resort $\left(l_{1}\right)$ and elevation $\left(l_{2}\right)$ were included as covariates in all analyses. The full ANOVA-model (Eq. 1) included the fixed factors 'plot pair' $\left(l_{3}\right)$ (plot on ski slope vs. control plot), 'grading' $\left(l_{4}\right)$ (plot pairs on machine-graded vs. un-graded ski slopes), and 'snow type' $\left(l_{5}\right)$ (plot pairs with natural vs. artificial snow) and the interactions 'grading $\times$ plot pair', 'grading $\times$ snow type' and 'plot pair $\times$ snow type'. Variables were transformed prior to analysis to meet the assumptions of ANOVA, using a square-root transformation (soil moisture, RLD and RD), arcsine square root transformation (vegetation cover, $\mathrm{pH}$, aggregate stability, gravel-, sand- and silt content) or log transformation (clay content).

$\mathrm{Y} \sim 1_{1}+1_{2}+\left(1_{3}+1_{4}+1_{5}\right)^{2}$

A posteriori contrasts were tested with Tukey HSD tests to distinguish significant differences between means of (a) plots on each ski slope type and their corresponding control plots (with a subset of the data containing at a time only plots of one ski slope type and their controls, Figs. 1 and 2), (b) plots from each ski slope type only and (c) only control plots belonging to one of the four ski slope types (with a subset of the data containing either only the ski slopes without controls or only control plots without plots on ski slopes, Table 6). The reduced ANOVA-models prior 
Fig. 1 Number of plant species, percentage vegetation cover, root density (RD) and root length density (RLD) for four ski slope types and adjacent control plots; NS: un-graded with natural snow, AS: un-graded with artificial snow, NSG: graded with natural snow, and ASG: graded with artificial snow (means \pm 1 SE). Significant differences between means are indicated as: $* * * P<$ $0.001,{ }^{*} P<<0.01, * P<0.05$, (*) $P<0.1$, ns $P>0.1$ (Tukey post hoc comparison between plots on each ski slope type and their corresponding control plots)
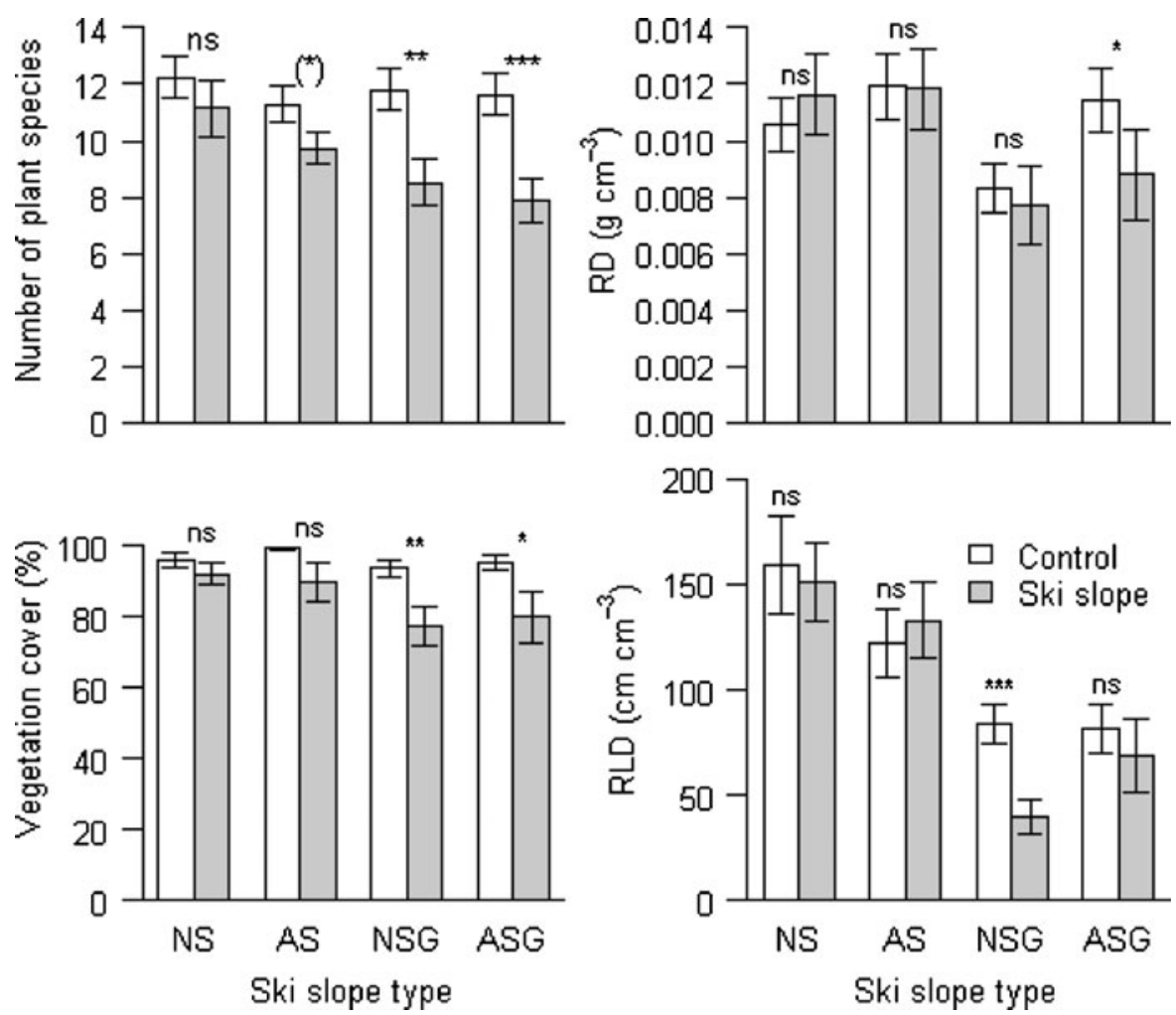

Tukey HSD tests were $\mathrm{Y} \sim 1_{1}+1_{2}+1_{3}$ for (a) and $\mathrm{Y} \sim$ $1_{1}+1_{2}+\left(1_{4}+1_{5}\right)^{2}$ for (b) and (c).

To understand the relationship between vegetation characteristics influencing aggregate stability, we plotted species number, vegetation cover and root density (Fig. 4). To enhance the visual information on the scatterplots, we applied a line smoother (R-function lowess) which uses locally-weighted polynomial regression (Cleveland 1979). The visual inspection of the shape of the line smoother suggested linear relationships between aggregate stability and the explanatory variables for low values but not throughout the entire data range. Piecewise regression did not yield break points in the data. However, to explore the nature of the respective relationships, we carried out analyses of the data range where linear based on visual inspection. For that data range, a linear regression model was then applied.

A multiple linear regression model (R-function rlm) was fitted with robust methods using an $\mathrm{M}$ estimator with the psi-function proposed by Hampel et al. (1986) and applying Huber's 'proposal 2' for scale estimation. The default model (Eq. 2) consisted of the numeric response variable 'soil aggregate stability' and three groups of explanatory variables representing characteristics of the study sites $\left(1_{1}-1_{5}\right)$, soil properties $\left(\mathrm{s}_{1}-\mathrm{s}_{6}\right)$ as well as vegetation characteristics $\left(\mathrm{v}_{1}-\mathrm{v}_{4}\right)$ (Table 2).

First aid transformations after Tukey (1957) were applied to the response variable (arcsine square root) and the explanatory variables soil density, organic matter, and root length density $\left(\log _{10}\right)$. Besides the main effects, all twofold interactions were considered (Eq. 2).

default model :

$\mathrm{Y} \sim\left(1_{1}+, \ldots,+1_{5}+\mathrm{s}_{1}+, \ldots,+\mathrm{s}_{6}+\mathrm{v}_{1}+, \ldots,+\mathrm{v}_{4}\right)^{2}$

Due to unbalanced design, a weighting factor $(\omega)$ was introduced considering the different numbers of specimens related to ski slope type, snow type, and sample site of the individual ski resorts. A stepwise backward selection process was applied to find a more parsimonious and explanatory model from a significance point of view (Stahel 2000; Venables and Ripley 
2002). The process resulted in a more explanatory yet easier model (Eq. 3), without significant loss of explanatory power $(\mathrm{F}=61.65, p=0.1011)$. Totally explained deviance accounted for $71 \%$.

selected model in R function : $\mathrm{r} 1 \mathrm{~m}\left(\right.$ formula $=\mathrm{Y} \sim 1_{1} \mathrm{~s}_{4}+\mathrm{s}_{2} \mathrm{v}_{2}+\mathrm{s}_{3} \mathrm{~s}_{6}+\mathrm{s}_{4} \mathrm{v}_{2}+\mathrm{v}_{1}\left(1_{4}+\mathrm{s}_{1}\right)+v_{4}$, data, weights $=\omega$, psi $=$ psi.hampel, scale.est $=$ "proposal $2^{\prime \prime}$, method $={ }^{\prime \prime} \mathrm{M}^{\prime \prime}$ )

Analysis of deviance tables using $\mathrm{F}$ test statistics were computed for the default and fitted model objects to test for significant loss of explanatory power. Residual analysis was conducted to check the compliance of the assumptions required and the fit of the final model. For that purpose residuals against fitted values (Tukey-Anscombe plot) and against leverages (hat matrix) were analysed as well as the residual distribution and the quantil-quantil plot.

The generic R-function confint (confidence interval), based on profile likelihoods, was applied to compute confidence intervals to test the different levels of the multileveled factor 'ski resort' against each other as well as its interaction terms. Additionally, the Pearson correlation of coefficients was calculated and the variance inflation factor (VIF) for multi-collinearity applied (O' Brien 2007). All analyses were performed using R, version 2.8.1 (R Development Core Team 2009).

\section{Results}

Impact of ski slope management on vegetation characteristics

Both the number of plant species and the vegetation cover were significantly reduced on ski slopes compared to control plots. Ski slopes had on average three plant species fewer and 12\% less plant cover than control plots (Fig. 1. and 'plot pair' in Table 3). This effect was even more pronounced in plots on graded ski slopes ('grading $\times$ plot pair' in Table 3, both $P<$ 0.1 ). Graded ski slopes had on average four plant species less and $12 \%$ less plant cover compared to un-graded ski slopes. The root length density was significantly lower in plots on graded ski slopes compared to un-graded ones ('grading $\times$ plot pair' in Table 3, $P<0.01$ ). Root density differed significantly between graded ski slopes with artificial snow and control plots (Fig. 1).
The vegetation on ski slopes was composed of $30 \%$ graminoids, $29 \%$ forbs, $9 \%$ shrubs, $10 \%$ mosses, and $5 \%$ lichens on average (Fig. 2). The cover of shrubs and lichen was lower on ski slopes than in control plots (7\% for shrubs, $P<0.001$, and $4 \%$ for lichen, $P<0.01$ ) ('plot pair' in Table 4). Comparing the four ski slope types, the majority of functional groups did not differ, but the cover of shrubs and lichen was significantly reduced on graded ski slopes ('grading x plot pair' in Table 4). Shrubs cover was five-times lower on graded ski slopes with natural snow compared to control plots, and 15times lower on graded ski slopes with artificial snow. Lichen cover was three-times lower on both graded ski slopes with natural or artificial snow.

Impact of ski slope management on abiotic soil properties

The proportion of bare ground was higher in plots on ski slopes compared to control plots (4 vs. $1 \%$ in Table 5 and 'plot pair' in Table $6, P<0.01)$, and did neither differ significantly between graded and un-graded ski slopes nor between the four ski slope types (Table 6). Gravel content was higher $(7 \%, P<0.05)$ and clay content was lower $(2 \%, P<0.01)$ in plots on ski slopes than in control plots ('plot pair' in Table 6). The content of sand and silt neither differed significantly between plots on ski slopes compared to control plots ('plot pair' in Table 6, $P>0.1$ ) nor between graded and un-graded ski slopes ('grading $\times$ plot pair' in Table $6, P>0.1$ ). The friction angle on ski slopes did not differ from adjacent control plots, but was significantly higher on graded ski slopes than on un-graded ones (35.1 vs. $34.4^{\circ}$, 'grading $\times$ plot pair' in Table $6, P<0.05)$. Organic matter content was $2 \%$ higher in control plots compared with plots on ski slopes ('plot pair' in Table $6, P<0.001$ ), but was not different in un-graded and graded plots. Soil density was higher in plots on ski slopes compared to control plots (Table 5 and 'plot pair' in Table 6, $P<$ 0.001 ), and on graded compared to un-graded ones 
Fig. 2 Percentage vegetation cover of five functional groups for four ski slope types; NS: un-graded with natural snow, AS: ungraded with artificial snow, NSG: graded with natural snow, and ASG: graded with artificial snow (means $\pm 1 \mathrm{SE}) . * * * P<0.001$, $* * P<0.01, * P<0.05$, ns $P>0.1$ (Tukey post hoc comparison between plots on each ski slope type and their corresponding

('grading $\times$ plot pair' in Table $6, P<0.001$ ). Soil moisture was significantly lower on ski slopes compared with control plots (31 vs. 39 wt. \%, 'plot pair' in Table 6, $P<0.001$ ), and lower on graded ski slopes when compared with un-graded ones $(22$ vs. 40 wt. \%, 'grading $\times$ plot pair' in Table $6, P<0.01)$. Aggregate stability was significantly lower on ski slopes than in control plots (49 vs. $57 \%, \mathrm{~F}_{(1,130)}=8.46, P<0.01$, Fig. 3), and was significantly reduced on graded ski slopes with artificial snow compared to control plots (44 vs. $62 \%$, $\left.\mathrm{F}_{(1,130)}=6.76, P<0.01\right)$.

Variables explaining variability in aggregate stability

Aggregate stability across all plots increased approximately linearly up to eight plant species, a vegetation cover of $70 \%$ and a root density of $0.006 \mathrm{~g} \mathrm{~cm}^{-3}$ on average (Fig. 4) according to the visual inspection of the line smoother. This was confirmed by linear regression across all plots: an increasing number of plant species up to eight species significantly increased aggregate stability up to $48 \%\left(\mathrm{r}^{2}=0.16, p<0.05\right.$, Fig. 4$)$. A vegetation cover up to $70 \%$ increased aggregate stability significantly up to $43 \%\left(\mathrm{r}^{2}=0.27, p<0.05\right)$, and a root density up to $0.006 \mathrm{~g} \mathrm{~cm}^{-3}$ aggregate stability was increased up to $52 \%\left(\mathrm{r}^{2}=0.16, p<0.05\right)$. Root density was positively correlated with a species number of $\leq 13\left(\mathrm{r}^{2}=0.11, p<0.001\right.$, not shown $)$.

In multiple regression analysis, the backward selection procedure eliminated 5 out of the 15 main effects as well as 99 out of the totally 105 two-fold interaction terms. The skipped main effects were elevation, plot pair, snow type, angle of internal friction, and biomass. The influence on aggregate stability was significantly different between the ski resorts Flims and Jakobshorn ( $p=0.008$, Table 7$)$, with a corresponding decrease of the intercept level of 0.331 . The ski slope type (graded vs. un-graded) had no significant influence on aggregate stability. Regarding soil classification, sand content strongly affected aggregate stability, and the difference in the mean value of aggregate
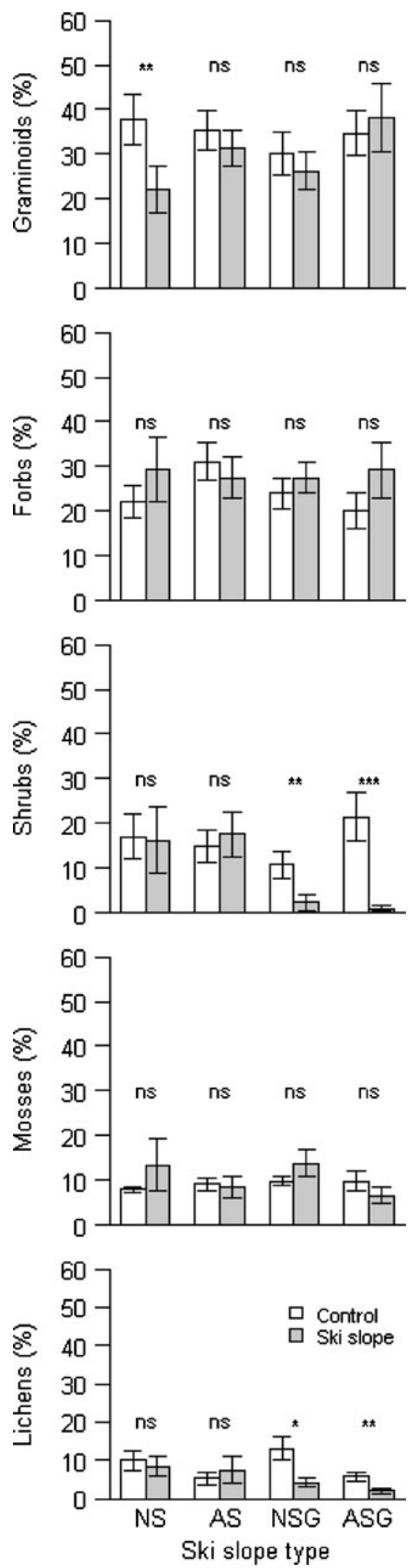
Table 2 Characteristics of the response variable and three groups of explanatory variables representing (a) characteristics of the study sites $\left(l_{l}-l_{5}\right)$, (b) soil properties $\left(s_{1}-s_{6}\right)$, and (c) vegetation characteristics $\left(v_{1}-v_{4}\right)$ considered in the multiple regression analysis

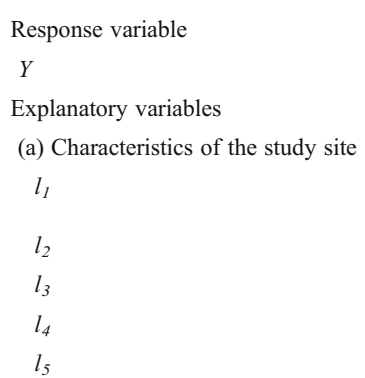

(b) Soil properties

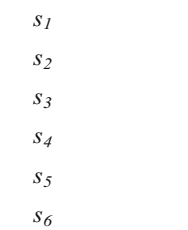

(c) Vegetation parameters

$\begin{array}{ll}v_{1} & \text { Number of plant species }(\mathrm{n}) \\ v_{2} & \text { Vegetation cover }(\%) \\ v_{3} & \text { Biomass }(\mathrm{g}) \\ v_{4} & \text { Root length density }\left(\mathrm{cm} \mathrm{cm}^{-3}\right)\end{array}$

(numeric: $\operatorname{asin} \sqrt{ }$ )

$\begin{array}{ll}\text { Ski resort }\left(l_{l a}: \text { Flims, } l_{l b}: \text { Jakobshorn, }\right. & \text { (3-levelled factor) } \\ \quad l_{l c}: \text { Lenzerheide) } & \text { (numeric) } \\ \text { Elevation (m asl) } & \text { (2-levelled factor) } \\ \text { Plot pair (on/off ski slope) } & \text { (2-levelled factor) } \\ \text { Grading (graded/ungraded) } & \text { (2-levelled factor) } \\ \text { Snow type (artificial/natural) } & \\ \text { Soil classification (gravel/sand) } & \text { (2-levelled factor) } \\ \text { Silt content (\%) } & \text { (numeric) } \\ \text { Clay content }(\%) & \text { (numeric) } \\ \text { Soil density (g cm }{ }^{-3} \text { ) } & \text { (numeric: } \log _{10} \text { ) } \\ \text { Angle of internal friction } \Phi^{\prime}\left({ }^{\circ}\right) & \text { (numeric) } \\ \text { Organic matter }(\%) & \text { (numeric: } \log _{10} \text { ) } \\ \text { Number of plant species }(\mathrm{n}) & \\ \text { Vegetation cover }(\%) & \text { (numeric) } \\ \text { Biomass (g) } & \text { (numeric) } \\ \text { Root length density }\left(\mathrm{cm} \mathrm{cm}^{-3} \text { ) }\right. & \text { (numeric) } \\ \end{array}$

stability between sandy soils and gravely soils was $0.812(p<0.001)$. The contents of silt and clay were both positively correlated with each other, however, only clay content significantly affected aggregate stability $(p<0.01)$. Organic matter was likewise positively correlated with aggregate stability and had after sand content the strongest significant influence on the slope of aggregate stability $(0.649, p<0.01)$. Soil density was negatively correlated with aggregate stability, while not significantly. Among vegetation characteristics, root length density had the strongest positive influence on aggregate stability $(0.255, p<0.01)$, followed by the number of plant species $(0.036 . p<0.01)$ and vegetation cover $(-0.013, p<0.05)$.

The interaction between ski resort and soil density resulted in a significant decrease of the slope by 1.586

Table 3 ANOVA table for the number of plant species, vegetation cover, root length density (RLD) and root density (RD)

\begin{tabular}{|c|c|c|c|c|c|c|c|c|c|c|}
\hline \multirow[t]{2}{*}{ Source of variation } & \multicolumn{3}{|c|}{ Number of plant species } & \multicolumn{2}{|c|}{ Vegetation cover $(\%)$} & \multicolumn{3}{|c|}{$\operatorname{RLD}\left(\mathrm{cm} \mathrm{cm}^{-2}\right)$} & \multicolumn{2}{|c|}{$\mathrm{RD}\left(\mathrm{g} \mathrm{cm}^{-3}\right)$} \\
\hline & DF & MS & $\mathrm{F}$ & MS & $\mathrm{F}$ & $\mathrm{DF}$ & MS & $\mathrm{F}$ & MS & $\mathrm{F}$ \\
\hline Elevation $\left(l_{2}\right)$ & 1 & 2.010 & 0.205 & 0.640 & $8.904 * *$ & 1 & 42.530 & $4.881^{*}$ & 0.011 & $14.289 * * *$ \\
\hline Ski resort $\left(l_{1}\right)$ & 2 & 64.370 & $6.563 * *$ & 0.316 & $4.398 *$ & 2 & 38.450 & $4.412 *$ & 0.001 & 1.306 \\
\hline Grading $\left(l_{4}\right)$ & 1 & 34.450 & $3.512(*)$ & 0.387 & $5.385^{*}$ & 1 & 355.740 & $40.821 * * *$ & 0.003 & $4.069^{*}$ \\
\hline Plot pair (on vs off) $\left(l_{3}\right)$ & 1 & 234.760 & $23.933 * * *$ & 1.461 & $20.321 * * *$ & 1 & 54.320 & $6.233^{*}$ & 0.002 & 2.101 \\
\hline Snow type $\left(l_{5}\right)$ & 1 & 2.140 & 0.218 & 0.024 & 0.338 & 1 & 0.960 & 0.110 & 8.E-05 & 0.098 \\
\hline Grading x plot pair & 1 & 38.230 & $3.898(*)$ & 0.200 & $2.781(*)$ & 1 & 66.170 & $7.593 * *$ & 0.002 & 2.431 \\
\hline Grading x snow type & 1 & 2.940 & 0.300 & 0.000 & 0.003 & 1 & 28.360 & $3.254(*)$ & 2.E-04 & 0.291 \\
\hline Plot pair x snow type & 1 & 2.100 & 0.214 & 0.005 & 0.063 & 1 & 19.740 & 2.265 & 3.E-04 & 0.323 \\
\hline Residuals & 130 & 9.810 & & 0.072 & & 126 & 8.710 & & 0.001 & \\
\hline
\end{tabular}

$D F$ degrees of freedom, $M S$ mean squares, $F$ variance ratio (see section on 'Statistical analysis in Material and methods' for model details)

$* * * P<0.001, * * P<0.01, * P<0.05,(*) P<0.1$, ns $P>0.1$ 
Table 4 ANOVA table for the cover percentage of five functional groups for four ski slope types

\begin{tabular}{|c|c|c|c|c|c|c|c|c|c|c|c|}
\hline \multirow[t]{2}{*}{ Source of variation } & \multicolumn{3}{|c|}{ Graminoids } & \multicolumn{2}{|l|}{ Forbs } & \multicolumn{2}{|c|}{ Shrubs } & \multicolumn{2}{|c|}{ Mosses } & \multicolumn{2}{|c|}{ Lichens } \\
\hline & $\mathrm{DF}$ & MS & $\mathrm{F}$ & MS & $\mathrm{F}$ & MS & $\mathrm{F}$ & MS & $\mathrm{F}$ & MS & $\mathrm{F}$ \\
\hline Elevation $\left(l_{2}\right)$ & 1 & 0.201 & $3.243(*)$ & 0.033 & 0.666 & 0.195 & $2.865(*)$ & 0.014 & 0.677 & 0.213 & $6.249^{*}$ \\
\hline Ski resort $\left(l_{1}\right)$ & 2 & 0.309 & $4.975 * *$ & 0.443 & $9.007 * * *$ & 0.644 & $9.461 * * *$ & 0.548 & $27.405^{* * *}$ & 0.325 & $9.533 * * *$ \\
\hline Grading $\left(l_{4}\right)$ & 1 & 0.015 & 0.245 & 0.215 & $4.372 *$ & 0.121 & 1.772 & 0.021 & 1.063 & 0.002 & 0.068 \\
\hline Plot pair (on vs off) $\left(l_{3}\right)$ & 1 & 0.085 & 1.373 & 0.055 & 1.118 & 0.865 & $12.716^{* * *}$ & 0.015 & 0.753 & 0.278 & $8.167 * *$ \\
\hline Snow type $\left(l_{5}\right)$ & 1 & 0.131 & 2.108 & 0.021 & 0.427 & 0.001 & 0.008 & 0.125 & $6.278^{*}$ & 0.153 & $4.480^{*}$ \\
\hline Grading x plot pair & 1 & 0.085 & 1.373 & 0.060 & 1.211 & 0.519 & $7.623^{* *}$ & 0.000 & 0.005 & 0.145 & $4.252 *$ \\
\hline Grading $x$ snow type & 1 & 0.166 & 2.678 & 0.007 & 0.150 & 0.002 & 0.028 & 0.085 & $4.237^{*}$ & 0.057 & 1.683 \\
\hline Plot pair x snow type & 1 & 0.129 & 2.082 & 0.002 & 0.034 & 0.048 & 0.701 & 0.059 & $2.935\left(^{*}\right)$ & 0.009 & 0.257 \\
\hline Residuals & 130 & 0.062 & & 0.049 & & 0.068 & & 0.020 & & 0.034 & \\
\hline
\end{tabular}

$D F$ degrees of freedom, $M S$ mean squares, $F$ variance ratio (see section on 'Statistical analysis in Material and methods' for model details)

$* * * P<0.001, * * P<0.01, * P<0.05,(*) P<0.1, P>0.1$

for the Lenzerheide ski resort compared to Flims ( $p<$ 0.05 ), and 2.383 when compared to Jakobshorn (difference of +0.7969 for Jakobshorn and -1.5865 for Lenzerheide, in Table 7, $p<0.05$ ). Significant and negative interaction effects were noticed for the number of plant species with ski slope type $(-0.037, p<0.05)$ and soil classification $(-0.072, p<0.001)$, i.e. on sandy and graded ski slopes both variables decreased the effect of

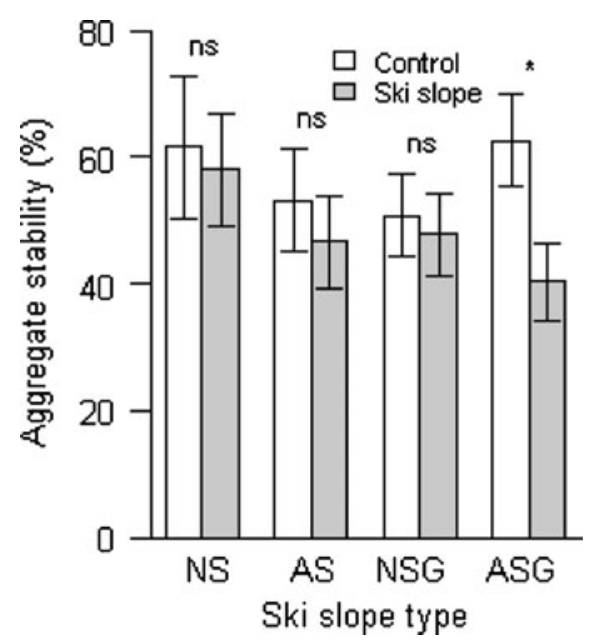

Fig. 3 Aggregate stability for four ski slope types; NS: ungraded with natural snow, AS: un-graded with artificial snow, NSG: graded with natural snow, and ASG: graded with artificial snow (means $\pm 1 \mathrm{SE}$ ). ${ }^{*} P<0.05$, ns $P>0.1$ (Tukey post hoc comparison between plots on each ski slope type and their corresponding control plots) the number of plant species on soil aggregate stability accordingly and compared to gravely and un-graded ski slopes. Therefore, the effect of the number of plant species on soil aggregate stability was more pronounced on graded and gravely than on un-graded and sandy ski slopes. Content of silt and vegetation cover interacted positively and significantly increased soil aggregate stability with an estimated slope of $0.0004(p<0.05)$. On the contrary, the negative interaction between content of clay and organic matter with an estimate of $-0.054(p<0.05)$ pointed to a significant competition effect related to soil aggregate stability, i.e. a high content of clay impeded a high content of organic matter and vice versa.

\section{Discussion}

Mechanical damages on soil and vegetation on graded ski slopes

Vegetation characteristics on un-graded ski slopes retained many similarities with adjacent control pastures. Although, the number of plant species was (marginally) reduced on un-graded ski slopes, the vegetation cover in general, and the cover of forbs, shrubs, mosses, and lichen in particular was not (see also Wipf et al. 2005). Machine-grading had a strong effect on vegetation (Pohl et al. 2009). Although, grading was carried out 16 to 44 years before this investigation was conducted, the 

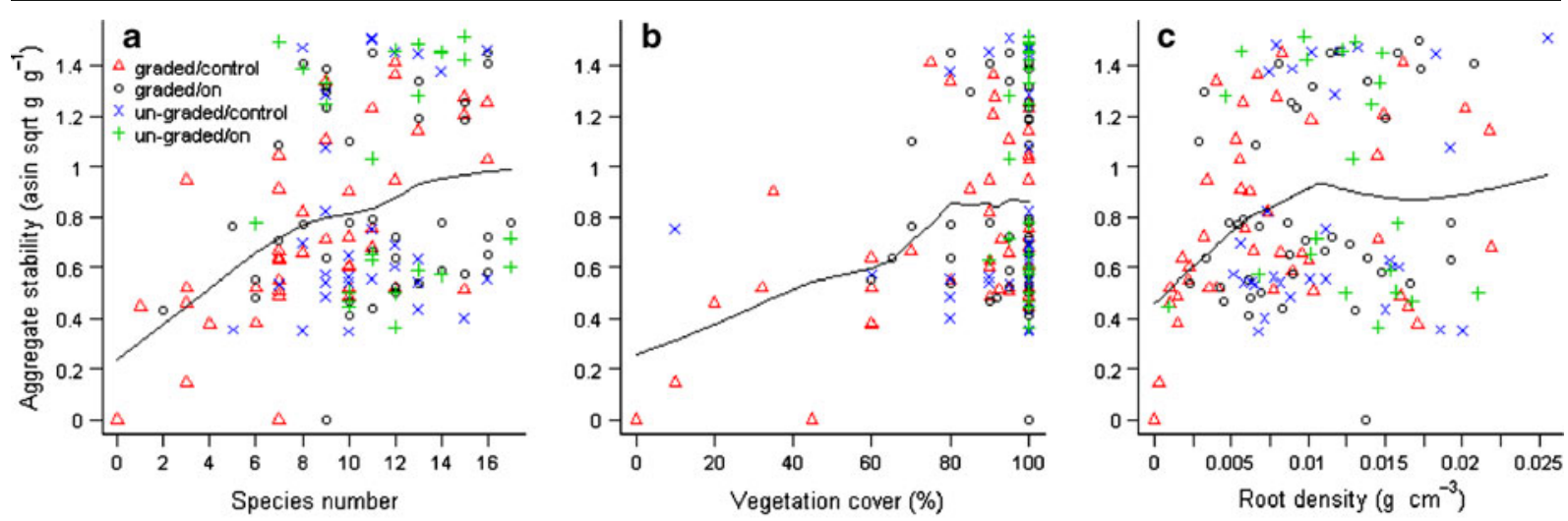

Fig. 4 Relationship between aggregate stability and (a) species number, (b) vegetation cover, and (c) root density for four ski slope types

vegetation has remained in a pioneer stage due to the disturbance (also Delgado et al. 2007; Wipf et al. 2005). The different times since machine-grading may have contributed to the variation in our data; however, it is common that disturbed soil do not recover easily, not even after decades (Keller et al. 2004; Wipf et al. 2005).

Table 5 Soil properties in plots on ski slopes and adjacent control plots (in parenthesis); NS: un-graded with natural snow, AS: un-graded with artificial snow, NSG: graded with natural snow, and ASG: graded with artificial snow (means $\pm 1 \mathrm{SE}$ ). Within a row, values that share a common letter do not differ
A recent resurvey of vegetation on disturbed ski slopes even showed that the percentage of open ground had increased although machine-grading had not been continued (Roux-Fouillet et al. 2011). The decrease in the number of plant species, vegetation cover and root (length) density is most probably due to the process of

significantly according to Tukey post hoc comparison only between plots on the four ski slope types, and only between the control plots in parenthesis $(P<0.05)$; other variables did not differ significantly among ski slope types or controls

\begin{tabular}{|c|c|c|c|c|}
\hline \multirow{2}{*}{$\begin{array}{l}\text { Soil } \\
\text { properties }\end{array}$} & \multicolumn{4}{|c|}{ Ski slope type } \\
\hline & NS & AS & NSG & ASG \\
\hline $\begin{array}{l}\text { Bare ground } \\
(\%)\end{array}$ & $\begin{array}{c}2.5 \pm 1.4 \\
(1.7 \pm 1.1)\end{array}$ & $\begin{array}{c}2.5 \pm 1.5 \\
(0.3 \pm 0.3)\end{array}$ & $\begin{array}{c}4.1 \pm 2.0 \\
(0.6 \pm 0.5)\end{array}$ & $\begin{array}{c}8.6 \pm 3.3 \\
(2.3 \pm 2.1)\end{array}$ \\
\hline Gravel (\%) & $\begin{array}{c}53.3 \pm 8.2 \\
(43.4 \pm 5.7) \mathrm{ab}\end{array}$ & $\begin{array}{l}50.2 \pm 5.5 \\
(50.5 \pm 6.1) \mathrm{ab}\end{array}$ & $\begin{array}{c}56.4 \pm 2.7 \\
(52.1 \pm 4.0) \mathrm{a}\end{array}$ & $\begin{array}{c}55.3 \pm 3.8 \\
(40.5 \pm 5.9) \mathrm{b}\end{array}$ \\
\hline Sand $(\%)$ & $\begin{array}{c}55.2 \pm 7.1 \\
(55.2 \pm 4.9)\end{array}$ & $\begin{array}{c}61.2 \pm 3.1 \\
(59.4 \pm 3.4)\end{array}$ & $\begin{array}{c}60.5 \pm 2.7 \\
(61.9 \pm 2.3)\end{array}$ & $\begin{array}{c}64.0 \pm 2.2 \\
(59.4 \pm 3.3)\end{array}$ \\
\hline Silt (\%) & $\begin{array}{c}35.9 \pm 6.0 \\
(34.9 \pm 4.2)\end{array}$ & $\begin{array}{c}30.4 \pm 2.9 \\
(29.8 \pm 2.8)\end{array}$ & $\begin{array}{c}30.2 \pm 2.2 \\
(28.6 \pm 2.3)\end{array}$ & $\begin{array}{c}27.8 \pm 1.9 \\
(28.3 \pm 2.0)\end{array}$ \\
\hline Clay (\%) & $\begin{array}{l}9.0 \pm 1.5 \mathrm{a} \\
(9.9 \pm 1.1) \mathrm{ab}\end{array}$ & $\begin{array}{r}8.4 \pm 1.0 \mathrm{ab} \\
(10.7 \pm 0.8) \mathrm{a}\end{array}$ & $\begin{array}{c}9.3 \pm 1.5 \mathrm{~b} \\
(9.6 \pm 0.9) \mathrm{b}\end{array}$ & $\begin{array}{r}8.1 \pm 1.6 \mathrm{ab} \\
(12.3 \pm 2.4) \mathrm{b}\end{array}$ \\
\hline $\begin{array}{l}\text { Organic matter } \\
(\%)\end{array}$ & $\begin{array}{c}5.70 \pm 0.9 \mathrm{a} \\
(6.25 \pm 0.6) \mathrm{a}\end{array}$ & $\begin{array}{c}7.32 \pm 0.7 \mathrm{a} \\
(8.79 \pm 0.8) \mathrm{a}\end{array}$ & $\begin{array}{c}3.57 \pm 0.4 \mathrm{~b} \\
(5.00 \pm 0.7) \mathrm{b}\end{array}$ & $\begin{array}{c}3.21 \pm 0.5 \mathrm{~b} \\
(6.93 \pm 1.1) \mathrm{a}\end{array}$ \\
\hline $\begin{array}{l}\text { Friction angle } \\
\left(\left(^{\circ}\right)\right.\end{array}$ & $\begin{array}{c}34.6 \pm 0.4 \mathrm{ab} \\
(35.5 \pm 0.5) \mathrm{a}\end{array}$ & $\begin{array}{c}34.1 \pm 0.4 \mathrm{a} \\
(35.7 \pm 0.4) \mathrm{b}\end{array}$ & $\begin{array}{c}34.6 \pm 0.4 \mathrm{ab} \\
(34.1 \pm 0.3) \mathrm{ab}\end{array}$ & $\begin{array}{c}35.5 \pm 0.4 \mathrm{~b} \\
(34.3 \pm 0.3) \mathrm{a}\end{array}$ \\
\hline $\begin{array}{l}\text { Soil density } \\
\left(\mathrm{g} \mathrm{cm}^{-3}\right)\end{array}$ & $\begin{array}{r}0.91 \pm 0.06 \mathrm{a} \\
(0.92 \pm 0.03)\end{array}$ & $\begin{array}{r}0.93 \pm 0.04 \mathrm{a} \\
(0.84 \pm 0.03)\end{array}$ & $\begin{array}{c}1.20 \pm 0.04 \mathrm{~b} \\
(1.01 \pm 0.03)\end{array}$ & $\begin{array}{c}1.18 \pm 0.04 \mathrm{~b} \\
(0.90 \pm 0.04)\end{array}$ \\
\hline Moisture (\%) & $\begin{array}{c}41.6 \pm 5.7 \mathrm{a} \\
(40.1 \pm 3.7)\end{array}$ & $\begin{array}{c}39.0 \pm 4.5 \mathrm{a} \\
(40.1 \pm 3.8)\end{array}$ & $\begin{array}{c}20.4 \pm 1.8 \mathrm{~b} \\
(30.8 \pm 2.4)\end{array}$ & $\begin{array}{c}21.7 \pm 2.4 \mathrm{~b} \\
(42.0 \pm 4.6)\end{array}$ \\
\hline $\mathrm{pH}$ & $\begin{array}{l}4.34 \pm 0.08 \mathrm{ab} \\
(4.36 \pm 0.07)\end{array}$ & $\begin{array}{c}4.33 \pm 0.05 \mathrm{a} \\
(4.24 \pm 0.03)\end{array}$ & $\begin{array}{l}4.9 \pm 0.2 \mathrm{ab} \\
(5.1 \pm 0.2)\end{array}$ & $\begin{array}{c}4.9 \pm 0.1 \mathrm{~b} \\
(4.4 \pm 0.1)\end{array}$ \\
\hline
\end{tabular}


Table 6 ANOVA table for the soil properties for four ski slope types

\begin{tabular}{|c|c|c|c|c|c|c|c|c|c|c|c|c|c|}
\hline & df & MS & $\mathrm{F}$ & df & MS & $\mathrm{F}$ & $\mathrm{df}$ & $\mathrm{MS}$ & $\mathrm{F}$ & MS & $\mathrm{F}$ & MS & $\mathrm{F}$ \\
\hline Source of variation & \multicolumn{3}{|c|}{ Bare soil } & \multicolumn{3}{|c|}{ Gravel } & \multicolumn{2}{|c|}{ Sand } & & \multicolumn{2}{|l|}{ Silt } & \multicolumn{2}{|l|}{ Clay } \\
\hline Elevation $\left(l_{2}\right)$ & 1 & 0.082 & $3.634(*)$ & 1 & 0.021 & 0.470 & 1 & 0.015 & 1.297 & 0.012 & 2.083 & 0.040 & 0.191 \\
\hline Ski resort $\left(l_{l}\right)$ & 2 & 0.092 & $4.087^{*}$ & 2 & 0.586 & $13.245 * * *$ & 2 & 0.717 & $62.738^{* * *}$ & 0.788 & $139.616^{* * *}$ & 6.031 & $29.003 * * *$ \\
\hline Grading $\left(l_{4}\right)$ & 1 & 0.040 & 1.771 & 1 & 0.028 & 0.638 & 1 & 0.074 & $6.438^{*}$ & 0.035 & $6.225^{*}$ & 1.925 & $9.257 * *$ \\
\hline Plot pair (on vs off) $\left(l_{3}\right)$ & 1 & 0.191 & $8.455^{* *}$ & 1 & 0.197 & $4.463^{*}$ & 1 & 0.004 & 0.355 & 0.002 & 0.270 & 2.278 & $10.954 * *$ \\
\hline Snow type $\left(l_{5}\right)$ & 1 & 0.042 & 1.847 & 1 & 0.153 & $3.463(*)$ & 1 & 0.000 & 0.008 & 0.003 & 0.538 & 0.502 & 2.414 \\
\hline Grading x plot pair & 1 & 0.030 & 1.343 & 1 & 0.020 & 0.448 & 1 & 0.000 & 0.001 & 0.000 & 0.011 & 0.011 & 0.053 \\
\hline Grading $x$ snow type & 1 & 0.052 & 2.289 & 1 & 0.127 & $2.865(*)$ & 1 & 0.048 & $4.241 *$ & 0.003 & 0.606 & 1.675 & $8.056 * *$ \\
\hline Plot pair x snow type & 1 & 0.015 & 0.657 & 1 & 0.005 & 0.114 & 1 & 0.016 & 1.391 & 0.002 & 0.280 & 0.185 & 0.891 \\
\hline Residuals & 130 & 0.023 & & 129 & 0.044 & & 130 & 0.011 & & 0.006 & & 0.208 & \\
\hline Source of variation & \multicolumn{3}{|c|}{ Friction angle } & \multicolumn{3}{|c|}{ Organic matter } & \multicolumn{3}{|c|}{ Soil density } & \multicolumn{2}{|c|}{ Soil moisture } & \multicolumn{2}{|l|}{$\mathrm{pH}$} \\
\hline Elevation $\left(l_{2}\right)$ & 1 & 0.776 & 0.321 & 1 & 0.002 & $3.845(*)$ & & 0.070 & 1.652 & 0.144 & $8.687 * *$ & 2.289 & $8.117 * *$ \\
\hline Ski resort $\left(l_{l}\right)$ & 2 & 19.994 & $8.263 * * *$ & 2 & 0.025 & $40.172 * * *$ & & 0.211 & $4.982 * *$ & 0.026 & 1.541 & 11.315 & $40.122 * * *$ \\
\hline Grading $\left(l_{4}\right)$ & 1 & 1.574 & 0.651 & 1 & 0.020 & $31.763 * * *$ & & 0.780 & $18.461^{* * *}$ & 0.236 & $14.238 * * *$ & 2.355 & $8.352 * *$ \\
\hline Plot pair (on vs off) $\left(l_{3}\right)$ & 1 & 1.980 & 0.818 & 1 & 0.012 & $19.145 * * *$ & & 0.792 & $18.740^{* * *}$ & 0.211 & $12.753 * * *$ & 0.207 & 0.732 \\
\hline Snow type $\left(l_{5}\right)$ & 1 & 9.315 & $3.850(*)$ & 1 & 0.004 & $5.893^{*}$ & & 0.100 & 2.359 & 0.003 & 0.176 & 0.240 & 0.851 \\
\hline Grading x plot pair & 1 & 12.978 & $5.364^{*}$ & 1 & 0.001 & 1.737 & & 0.257 & $6.084^{*}$ & 0.139 & $8.405 * *$ & 0.036 & 0.126 \\
\hline Grading x snow type & 1 & 1.359 & 0.562 & 1 & $1.5 \mathrm{E}-04$ & 0.235 & & 0.014 & 0.320 & 0.025 & 1.532 & 0.346 & 1.227 \\
\hline Plot pair x snow type & 1 & 5.175 & 2.139 & 1 & 0.002 & $3.490(*)$ & & 0.063 & 1.495 & 0.017 & 1.011 & 1.277 & $4.529 *$ \\
\hline Residuals & 130 & 2.420 & & 129 & 0.001 & & & 0.042 & & 0.017 & & 0.282 & \\
\hline
\end{tabular}

$D F$ degrees of freedom, $M S$ mean squares, $F$ variance ratio (see section on 'Statistical analysis in Material and methods' for model details)

$* * * P<0.001, * * P<0.01, * P<0.05,(*) P<0.1, P>0.1$

machine-grading itself, which is carried out in summer to remove slope irregularities, but considerably affects the vegetation at the same time. Functional groups such as shrubs and lichens were particularly susceptible to mechanical damage on graded ski slopes resulting in lower cover. The machine-grading may furthermore reduce the soil pores greater than $10 \mu \mathrm{m}$ that are important for root growth of plants (Scheffer 2002). Consequently, aeration and soil moisture capacity decrease which further restrict root growth. Snow type showed hardly any effect on vegetation characteristics in our study. The reason might be that artificial snow production is a less severe intervention than grading which might mask potential effects of artificial snow (Rixen et al. 2008; Rixen et al. 2004; Wipf et al. 2005).

Soil properties on un-graded ski slopes were marginally different from adjacent control plots. Machinegrading reduced aggregate stability and soil moisture, and increased soil density and friction angle compared to un-graded ski slopes (Pohl et al. 2009). Aggregate stability on graded ski slopes was probably lower due to the reduced number of plant species, vegetation cover and root density (Roux-Fouillet et al. 2011).
The effect that aggregate stability increases with soil density was apparently smaller than the decrease of aggregate stability with lower root density. Our study shows that especially the root density had a strong positive correlation with aggregate stability (discussed below). Roots enmesh fine particles of the soil into stable macroaggregates and release organic carbon (related to the total length of roots) which further acts as binding agent (Tisdall and Oades 1982). The higher friction angle on graded ski slopes compared to ungraded ones is probably due to the more consolidated soil through the former machine-grading, as the friction angle increases with increasing soil density (Graf et al. 2009; Terzaghi and Peck 1967). To date, most investigations on the influence of vegetation on slope stability have depended on direct shear tests, and the increase in shear strength due to roots has normally been attributed to a higher apparent cohesion (e.g. Cazzuffi et al. 2006; Wu and Watson 1998). However, Graf et al. (2009) showed that the increase in shear strength of a cohesionless moraine due to roots is exclusively based on an increase of the friction angle. Although not directly applicable in our study, the 
Table 7 Multiple regression between aggregate stability and three groups of explanatory variables representing characteristics of the study sites $\left(l_{1}-l_{5}\right)$, soil properties $\left(s_{1}-s_{6}\right)$ as well as vegetation characteristics $\left(v_{1}-v_{4}\right)$ as indicated in Table 5. Confidence intervals for the 3-levelled factor ski resort and its interaction terms $\left(1_{1 \mathrm{a}}\right.$ : baseline level Flims $\left.\equiv 0\right)$ are given below

\begin{tabular}{|c|c|c|c|c|c|}
\hline Coefficients & & Estimate & Std. Error & $\mathrm{t}$ value & $\operatorname{Pr}(>|t|)$ \\
\hline \multicolumn{2}{|l|}{ Intercept } & 0.6627 & 0.5901 & 1.1229 & 0.2640 \\
\hline$l_{1 b}$ & Ski resort [Jakobshorn] & -0.3313 & 0.1215 & -2.7263 & $0.0075^{* *}$ \\
\hline$l_{l c}$ & Ski resort [Lenzerheide] & -0.2246 & 0.1312 & -1.7111 & $0.0900(*)$ \\
\hline$l_{4 b}$ & Ski slope type [ungraded] & 0.1702 & 0.1786 & 0.9530 & 0.3430 \\
\hline$s_{1 b}$ & Soil classification [sand] & 0.8124 & 0.2262 & 3.5922 & $0.0005^{* * *}$ \\
\hline$s_{2}$ & Silt content & -0.0296 & 0.0189 & -1.5699 & 0.1190 \\
\hline$s_{3}$ & Clay content & 0.0600 & 0.0221 & 2.7172 & $0.0077 * *$ \\
\hline$s_{4}$ & Soil density & -0.5125 & 0.4026 & -1.2729 & 0.2060 \\
\hline$s_{6}$ & Organic matter & 0.6490 & 0.2197 & 2.9540 & $0.0039 * *$ \\
\hline$v_{1}$ & Number of plant species & 0.0356 & 0.0107 & 3.3390 & $0.0012 * *$ \\
\hline$v_{2}$ & Vegetation cover & -0.0134 & 0.0053 & -2.5237 & $0.0131 *$ \\
\hline$v_{4}$ & Root length density & 0.2546 & 0.0894 & 2.8482 & $0.0053 * *$ \\
\hline$l_{1 b}: s_{4}$ & Jakobshorn : soil density & 0.7969 & 0.5453 & 1.4613 & 0.1470 \\
\hline$l_{1 c}: s_{4}$ & Lenzerheide : soil density & -1.5865 & 0.6548 & -2.4230 & $0.0171^{*}$ \\
\hline$l_{4 b}: v_{1}$ & Grading [ungraded] : Number of plant species & -0.0374 & 0.0163 & -2.2967 & $0.0236^{*}$ \\
\hline$s_{1 b}: v_{I}$ & Soil classification [sand] : Number of plant species & -0.0719 & 0.0199 & -3.6170 & $0.0005^{* * *}$ \\
\hline$s_{2}: v_{2}$ & Silt content : vegetation cover & 0.0004 & 0.0002 & 2.1066 & $0.0375^{*}$ \\
\hline$s_{3}: s_{6}$ & Clay content: organic matter & -0.0540 & 0.0253 & -2.1345 & $0.0351^{*}$ \\
\hline \multicolumn{6}{|c|}{ Residual standard error: 0.1571 on 108 degrees of freedom, $n=126$, deviance explained $=70.4 \%$} \\
\hline \multicolumn{6}{|c|}{ Confidence intervals of the 3 -levelled factor ski resort $\left(1_{1 \mathrm{a}}:\right.$ baseline level "Flims" $\left.\equiv 0\right)$} \\
\hline & & $2.50 \%$ & $97.50 \%$ & & \\
\hline$l_{1 b}$ & Ski resort [Jakobshorn] & -0.5555 & -0.0757 & & \\
\hline$l_{l c}$ & Ski resort [Lenzerheide] & -0.4662 & 0.0519 & & \\
\hline$l_{1 b}: s_{4}$ & Ski resort [Jakobshorn] : soil density & -0.3663 & 1.7866 & & \\
\hline$l_{1 c}: s_{4}$ & Ski resort [Lenzerheide] : soil density & -2.9833 & -0.3983 & & \\
\hline
\end{tabular}

Significant differences between means are indicated as: $* * * P<0.001, * * P<0.01, * P<0.05,(*) P<0.1$

vegetation effect on soil stability could thus be interpreted by a higher friction angle of the soil.

Variables explaining variability in aggregate stability

Previous studies on vegetation and soil mechanic aspects found that the behaviour of soil at low density reinforced with plants is comparable to soil without roots at higher density (Frei et al. 2003; Graf et al. 2009). Therefore, the plants' effect on soil stability in terms of the angle of internal friction $\Phi^{\prime}$ equals the increase in density of a pure soil. The aforementioned conclusions are true for soil material found after serious erosion or landslide events, generally characterised by loose mixtures of grains with only small proportions of fine fractions and organic matter. This applies also to alpine ski slopes, particularly for graded ones (Graf 1997; Graf et al. 2009). Correspondingly, one has to be aware, that in further developed soil, other important stabilising effects, i.e. organic matter, chemical compounds, etc. compete with the geotechnical parameters and mask the pure soil mechanical approach.

Silt content was negatively correlated with aggregate stability (though not significantly) indicating that loamy soils are generally more susceptible to soil erosion (Coppin and Richards 1990; Gerber et al. 2002) and, consequently, as percentage of silt increases, soil aggregate stability decreases. However, high proportions of fine soil fractions are not necessarily disadvantageous for aggregate stability. On the contrary, Graf (1997) on graded ski slopes in the alpine zone found that higher silt and fine sand fractions may positively influence 
aggregate stability and, accordingly, the resistance against erosion. This positive effect on aggregate stability was attributed to the vegetation which was more developed on the sites with the most erosive soil than elsewhere. The significant difference in intercept between gravely and sandy soils in multiple regression analysis might, therefore, reflect an advanced development stage in view of soil aggregate formation and stabilisation of soils with a certain amount of fine fractions (Graf 1997; Graf et al. 2009). This assumption is further supported by the significant and positive interaction between the silt content and vegetation cover. The fine soil fractions provide the basic particles for the production of soil aggregates, mainly formed and stabilised by micro-organisms and plant roots (Lynch and Bragg 1985; Miller and Jastrow 1992; Rillig and Mummey 2006; Tisdall et al. 1997). These aggregates largely contribute to the soil structure, which, in turn, is known to influence water and nutrient (retention) capacity and, therefore, affect root growth and plant performance (Gliński and Lipiec 1990; Kramer 1983; Miller and Jastrow 2000).

Although not significant, the negative relationship between soil density and aggregate stability needs careful interpretation. A closer look at the significant interaction effect reveals that the negative influence is true for the ski resorts Flims and Lenzerheide but not for Jakobshorn. From agriculture it is known that continuously cultivated soils are often compacted and have low organic matter content. Such soils are known to have low aggregate stability in contrast to soils that have not experienced continuous cultivation (Aina 1979; Idowu 2003). Regarding our ski slopes it turns out that soil density is higher at sites with lower organic matter; confirmed by the highest correlation value (Pearson's product-moment correlation $\mathrm{r}=0.62$ ) of all pair-wise comparisons. Therefore, the negative relationship may reflect the extent of soil degradation that has occurred over time, which has influenced soil parameters such as organic matter, which contributes directly to the formation of stable aggregates (Tisdall and Oades 1982). At Jakobshorn the values of aggregate stability and soil density are significantly lower and those of organic matter higher, compared to Flims and Lenzerheide. It seems, therefore, that the ski resort Jakobshorn did not suffer as much from compaction and loss of organic matter.

It is well known, that high soil density and, related to that, high penetration resistance, inhibit root growth
(Hettiaratchi 1990). If under compacted soil conditions the vegetation cover is unexpectedly high, it may be concluded that the corresponding plant species are shallow rooting, or the cover is mainly composed of mosses and lichens. In both cases aggregate stability is hardly influenced by plants and cryptogams, respectively. If aggregate stability is nonetheless high, it is probably exclusively due to enhanced soil density (Frei et al. 2003). Contrary, at low soil density and high aggregate stability, the latter is mainly due to roots and associated micro-organisms. Conclusively, high soil aggregate stability is either a result of plants at low soil density or of density at low plant cover, reflecting the approach of 'virtual density' (Böll and Graf 2001), verified by Frei et al. (2003) and others (Frei 2009; Graf et al. 2009).

All vegetation parameters remaining in the multiple regression model significantly influenced soil aggregate stability. In this context, root length density proved most important with an estimate for slope of 0.255 followed by species diversity $(0.036)$ and vegetation cover $(-0.013)$. The soil stabilising effect of plants is well known and widely applied in numerous techniques of soil bioengineering including restoration measures on alpine ski slopes (Gray and Sotir 1996; Morgan and Rickson 1995; Urbanska 1997). Roots play a key role in soil stabilising in general (Morgan and Rickson 1995) as well as in assembling soil aggregates in particular (Gyssels and Poesen 2003). Although not studied here, soil aggregation is even more pronounced combined with their natural symbiotic fungal partners (Graf et al. 2006; Miller and Jastrow 1992; Rillig and Mummey 2006; Tisdall et al. 1997). Root and hyphal growth stimulate microbial activity and simultaneously promote the formation of macro-aggregates (Denef and Six 2005). Aggregates up to $1 \mathrm{~mm}$ are predominantly assembled by fungal hyphae, mechanically through entanglement of soil particles and chemically with glue-like metabolites (Bearden 2001; Rillig and Mummey 2006). Pohl et al. (2009) found a positive and significant correlation between root length density and soil aggregate stability in general and for fine roots in particular but not for coarse roots. However, as the fine roots are the 'docking stations' for mycorrhizal fungi, it can be presumed, that the effect of the fine roots includes the contribution of the associated fungal partners.

The main effect of plant species diversity on soil aggregate stability was positive (0.036). In 
consideration of the significant interaction effects with ski slope type and soil classification, it becomes apparent that the positive influence reflects only the situation on gravely soils and graded ski slopes. On un-graded compared to graded ski slopes $(-0.037)$ and sandy compared to gravely soils $(-0.072)$, however, species diversity seems to negatively affect aggregate stability. The reason for this might be explained by estimating thresholds for the positive effect of vegetation on aggregate stability. Aggregate stability increased linearly up to approximately eight plant species, $70 \%$ vegetation cover and $0.006 \mathrm{~g} \mathrm{~cm}^{-3}$ root density. Above those values, further increase in aggregate stability was less apparent. We assume that on sites with higher species number, vegetation cover, and root density, as mostly found on un-graded ski slopes and the surrounding area, aggregate stability is not further increased. We speculate that the soil is sufficiently stabilised by vegetation and other soil properties are more developed than on graded ski slopes. Also the root density was not further increased with more than 13 plant species. Although our separation of the data into different ranges was based on visual inpection only and did not hold piecewise regression techniques, the ranges are in agreement with previous findings: Mosimann (1981) found that a vegetation cover of $70 \%$ is sufficient to stabilise the soil surface against erosion on alpine slopes. Martin et al. (2010) showed that surface erosion is significantly reduced by a vegetation cover of $60 \%$, and that a higher number of plant functional groups better stabilised soil than a few number due to a higher number of root types (Pohl et al. 2011).

Within this scope, it has to be kept in mind, that prior to soil aggregate formation the necessary fine particles need to be trapped and kept on place. This is particularly essential on coarse grained and/or instable soils. Such conditions are often left after construction work and may stay for longer time-spans, facilitating erosion and depletion processes if adequate re-vegetation measures are neglected (Urbanska 1997). Sustainable sediment trapping is, therefore, an initiating step to interactive processes including soil aggregate formation and stabilisation, plant growth and establishment as well as succession in direction to a protective vegetation cover (Graf 1997; Graf et al. 2009). During this primary phase, roots and associated microorganisms are the main drivers for soil aggregate stability. Knowing that root morphology and architecture play a key role in this process, it is plausible that the effect of diversity is particularly pronounced on gravely and depleted soils as often represented by alpine ski slopes (Pohl et al. 2009).

\section{Conclusion}

The results from this study illustrate how machinegrading on ski slopes has a much larger effect on vegetation and soil properties than other factors on ski slopes such as skiing in general. At the same time, plant species richness, vegetation cover and root density were more important to provide high aggregate stability at disturbed machine-graded sites that at sites with fewer disturbances. Our study helps to understand mechanisms of the relationship between plant diversity and soil aggregate stability. We showed that plant species richness and other vegetation parameters are positively related with aggregate stability at low to medium values but much less at high values. Most likely plants have highly positive effects in disturbed and therefore relatively young soils. But in less disturbed and therefore older soils other parameters like more developed vegetation characteristics or organic matter become relatively more important, which obscures the diversity-aggregate stability relationship. Our study suggests that high plant diversity, vegetation cover and root density need to be established after major human disturbances such as grading in steep alpine terrain.

Acknowledgments We would like to thank the Swiss MAVAFoundation and the Swiss Federal Research Institute WSL for the financial support. We thank Dominik Alig and Nils Peuse for the great assistance in the field, as well as Adrian Käser and Niklaus Hardegger for their valuable laboratory work. Sabine Güsewell and the two anonymous referees helped improve this manuscript with useful comments.

\section{References}

Aina PO (1979) Soil changes resulting from long-term management practices in western Nigeria. Soil Sci Soc Am J 43:173-177

Amezketa E (1999) Soil aggregate stability: a review. J Sustain Agr 14:83-151

Barthès B, Roose E (2002) Aggregate stability as an indicator of soil susceptibility to runoff and erosion; validation at several levels. CATENA 47:133-149 
Bearden BM (2001) Influence of arbuscular mycorrhizal fungi on soil structure and soil water characteristics of vertisols. Plant Soil 229:245-258

Bird SB, Herrick JE, Wander MM, Murray L (2007) Multi-scale variability in soil aggregate stability: implications for understanding and predicting semi-arid grassland degradation. Geoderma 140:106-118

Bisutti I, Hilde I, Raessler M (2004) Determination of total organic carbon - an overview of current methods. Trends Anal Chem 23:716-726

Böll A, Graf F (2001) Nachweis von Vegetationswirkungen bei oberflächennahen Bodenbewegungen-Grundlagen eines neuen Ansatzes. Schweizerische Zeitschrift für Forstwesen 152:1-11

Cazzuffi D, Corneo A, Crippa E (2006) Slope stabilisation by perennial "gramineae" in southern Italy: plant growth and temporal performance. Geotech Geol Eng 24:429-447

Cleveland WS (1979) Robust locally weighted regression and smoothing scatterplots. J Am Stat Assoc 74:829-836

Coppin R, Richards IG (1990) Use of vegetation in civil engineering. CIRIA, Butterworths

Delgado R, Sanchez-Maranon M, Martin-Garcia JM, Aranda V, Serrano-Bernardo F, Rosua JL (2007) Impact of ski pistes on soil properties: a case study from a mountainous area in the Mediterranean region. Soil Use Manag 23:269-277

Denef K, Six J (2005) Claymineralogy determines the importance of biological versus abiotic processes formacroaggregate formation and stabilization. Eur J Soil Sci 56:469-479

Elridge DJ, Leys JF (2003) Exploring some relationships between biological soil crusts, soil aggregation and wind erosion. J Arid Environ 53:457-466

Frei M (2009) Validation of a new approach to determine vegetation effects on superficial soil movements. ETH Zürich.

Frei M, Boll A, Graf F, Heinimann HR, Springmann S (2003) Quantification of the influence of vegetation on soil stability. In: Lee CF, Tham LG (eds) Proceedings of the international conference on slope engineering. University of Hong Kong, Hong Kong, China, Department of Civil Engineering, pp 872-877

Gee GW, Bauder JW (1986) Particle-size analysis. In: Klute A (ed) Methods of soil analysis. Part 1, Physical and mineralogical methods. American Society of Agronomy, Madison, pp 383-411

Gerber W, Rickli C, Graf F (2002) Wind-throw and surface erosion. In: W. Schönenberger (ed) Vivian's legacy in Switzerland - impacts of windthrow on forest dynamics. Forest Snow and Landscape Research, pp 109-116

Gliński J, Lipiec J (1990) Soil physical conditions and plant roots. CRC Press, Boca Raton

Graf F (1997) Ectomycorrhiza in alpine soil bioengineering. Rev Valdotaine Hist Nat 52:335-342

Graf F, Frei M, Schwarz M, Böll A (2006) Use and importance of mycorrhiza in site-specific restoration. In: Krautzer B, Hacker E (ed) Soil-bioengineering: ecological restoration with native plant and seed material. HBLFA RaumbergGumpenstein Gumpenstein, pp 155-160.

Graf F, Frei M, Böll A (2009) Effects of vegetation on the angle of internal friction of a moraine. For Snow Landsc Res 82:61-77

Gray DH, Sotir RB (1996) Biotechnical and soil bioengineering slope stabilization: a practical guide for erosion control. Wiley, New York
Gyssels G, Poesen J (2003) The importance of plant root characteristics in controlling concentrated flow erosion rates. Earth Surf Proc Land 28:371-384

Hampel FR, Ronchetti EM, Rousseeuw PJ, Stahel WA (1986) Robust statistics - the approach based on influence functions. Wiley.

Hettiaratchi D (1990) Soil compaction and plant root growth. Phil Trans Roy Soc Lond B 329:343-355

Idowu OJ (2003) Relationships between aggregate stability and selected soil properties in humid tropical environment. Comm Soil Sci Plant Anal 34:695-708

Keller T, Pielmeier C, Rixen C, Gadient F, Gustafsson D, Staehli M (2004) Impact of artificial snow and ski-slope grooming on snowpack properties and soil thermal regime in a subalpine ski area. Ann Glaciol 38:314-318

Körner C, Spehn E M (eds) (2002) Mountain biodiversity: a global assessment. Parthenon Publishing Group, London, UK. pp. 336.

Kramer PJ (1983) Water relations of plants. Academic, New York

Lynch JM, Bragg E (1985) Microorganisms and soil aggregate stability. In: Stewart B (ed) Advances in soil science, Vol. II. Springer Verlag, New York, pp 133-169

Márquez CO, Garcia VJ, Cambardella CA, Schultz RC, Isenhart TM (2004) Aggregate-size stability distribution and soil stability. Soil Sci Soc Am J 68:725-735

Martin C, Pohl M, Alewell C, Körner C, Rixen C (2010) Interrill erosion at disturbed alpine sites: effects of plant functional diversity and vegetation cover. Basic Appl Ecol 11:619626

Miller RM, Jastrow JD (2000) Mycorrhizal fungi influence soil structure. In: Kapulnik Y, Douds DD (eds) Arbuscular mycorrhizas: molecular biology and physiology. Kluwer, Dordrecht, pp 3-18

Miller RM, Jastrow JD (1992) The application of VA mycorrhizae to ecosystem restoration and reclamation. In: Allen M (ed) Mycorrhizal functioning. Chapman \& Hall, New York, pp 438-467

Morgan RPC, Rickson RJ (1995) Slope stabilization and erosion control: a bioengineering approach. Spon, London

Mosimann T (1981) Geoökologische Standortsindikatoren für die Erosionsanfälligkeit alpiner Hänge nach Geländeeingriffen für Pistenanlagen. Geomethodica 6:143-174

O' Brien RM (2007) A caution regarding rules of thumb for variance inflation factors. Quality \& Quantity 41:673-690

Pohl M, Alig D, Körner C, Rixen C (2009) Higher plant diversity enhances soil stability in disturbed alpine ecosystems. Plant Soil 324:91-102

Pohl M, Stroude R, Buttler A, Rixen C (2011) Functional traits and root morphology of alpine plants. Ann Bot 108:537-545

R Development Core Team (2009) R: a language and environment for statistical computing. R Foundation for Statistical Computing, Vienna, Austria. URL http://www.R-project.org.

Rillig MC, Mummey DL (2006) Mycorrhizas and soil structure. New Phytol 171:41-53

Rixen C, Haeberli W, Stoeckli V (2004) Ground temperatures under ski pistes with artificial and natural snow. Arctic Antarct Alpine Res 36:419-427

Rixen C, Freppaz M, Stoeckli V, Huovinen C, Huovinen K, Wipf S (2008) Altered snow density and chemistry change soil nitrogen mineralization and plant growth. Arctic Antarct Alpine Res 40:568-575 
Roux-Fouillet P, Wipf S, Rixen C (2011) Long-term impacts of ski piste management on alpine vegetation and soils. $\mathrm{J}$ Appl Ecol 48:906-915

Scheffer F (2002) Lehrbuch der Bodenkunde / Scheffer, Schachtschabel. Spektrum Akademischer Verlag GmbH, Heidelberg, p 593

Schindler Wildhaber Y, Bänninger D, Burri K, Alewell C (2011) Evaluation and application of a portable rainfall simulator on subalpine grassland. CATENA. doi:10.1016/j.catena. 2011.03.004

Shinjo H, Fujita H, Gintzburger G, Kosaki T (1999) Soil aggragate stability under different landscapes and vegetation types in a semiarid area in northeastern Syria. Soil Sci Plant Nutr 46:229-240

SN670005a (1997) Schweizer Norm-Identifizierung der Lockergesteine: Feldmethode. Technical report. Vereinigung Schweizer Strassenfachleute VSS, Zürich, pp. 6.

SN670008a (1997) Schweizer Norm-Identifizierung der Lockergesteine: Labormethoden mit Klassifikation nach USCS. Technical report. Vereinigung Schweizer Strassenfachleute VSS, Zürich, pp. 6.

SN670010b (1999) Schweizer Norm-Bodenkennziffern: Labormethode mit Klassifikation nach USCS. Technical report. Vereinigung Schweizer Strassenfachleute VSS, Zürich, pp. 13.

Stahel WA (2000) Statistische Datenanalyse. Vieweg Verlag, Braunschweig, p 379
Stokes A, Atger C, Bengough AG, Fourcaud T, Sidle RC (2009) Desirable plant root traits for protecting natural and engineered slopes against landslides. 0032-079X. 324:1-30.

Terzaghi K, Peck RB (1967) Soil mechanics in engineering practice. Wiley, New York

Tisdall JM, Oades JM (1982) Organic-matter and water-stable aggregates in soils. Journal of Soil Science 33:141-163

Tisdall JM, Smith SE, Rengasamy P (1997) Aggregation of soil by fungal hyphae. Aust J Soil Res 35:55-60

Tukey JW (1957) On the comparative anatomy of transformations. Ann Math Stat 28:602-632

Urbanska KM (1997) Restoration ecology research above the timberline: colonization of safety islands on a machinegraded alpine ski run. Biodivers Conserv 6:1655-1670

Venables WN, Ripley BD (2002) Modern applied statistics with S. Springer, New York

Wick AF, Ingram LJ, Stahl PD (2009) Aggregate and organic matter dynamics in reclaimed soils as indicated by stable carbon isotopes. Soil Biol Biochem 41:201-209

Wipf S, Rixen C, Fischer M, Schmid B, Stoeckli V (2005) Effects of ski piste preparation on alpine vegetation. J Appl Ecol 42:306-316

Wu T, Watson A (1998) In situ shear tests of soil blocks with roots. Can Geotech J 35:579-590

Zuazo VHD, Pleguezuelo CRR (2008) Soil-erosion and runoff prevention by plant covers. A review. Agron Sustain Dev 28:65-86 